\title{
ANALISIS JANUARY EFFECT TERHADAP SAHAM INDEK KOMPAS 100
}

\author{
Noviarti', Selvi Pratama ${ }^{2}$ \\ noviarti.arif@gmail.com
}

1) Dosen Tetap Jurusan Manajemen FEB, Universitas Satya Negara Indonesia - Jakarta

\begin{abstract}
The purpose of this study is to determine whether there is a January Effect on the Kompas 100 Index. If there is a difference between abnormal returns in January and abnormal returns after January, there will be a January Effect and vice versa. The data used is secondary data. This researcher uses a population of companies listed in the Kompas 100 Index. The method of determining the sample is by using purposive sampling. The observation period is from January to December 2020. This study uses the Mann Whitney U Test to perform a different test. The results of this study indicate that there is a significant difference between the abnormal return value in January and the abnormal return value after January where the results of the study have a significance value of $0.000<0.05$.
\end{abstract}

\section{Keywords: January Effect, Abnormal Return. Compass Index100}

\section{A. PENDAHULUAN}

Di pasar modal Indonesia terjadinya overreaction pada saham dikarenakan adanya pembalikan rata-rata saham loser dari winner yang mengindikasikan terjadinya koreksi yang cepat untuk loser dibandingkan winner. Fenomena ini menunjukan para investor melakukan pembelian ataupun penjualan saham dengan cepat dan dengan reaksi yang berlebihan dan tidak rasional. Karena Reaksi yang berlebihan dari perilaku pasar inilah yang mendasari terjadinya overreaction. Saham-saham yang bernilai rendah(loser) dan kurang dininati akan mulai dicari pasar. Perilaku pasar seperti ini akan menyebabkan return saham yang sebelumnya rendah akan menjadi tinggi. Abnormal Return dapat digunakan untuk mengetahui rasionalitas investor dalam mengambil keputusan berinvestasi pada saham. Overreaction dapat juga disebabkan oleh informasi yang diterima investor tidak sesuai dengan ekspektasinya sehingga menimbulkan reaksi yang tidak wajar atau belebihan tanpa melakukan analisa pasar atau melakukan analisa fundamental. Apabila informasi bed news yang diterima investor maka saham cendrung dinilai terlalu rendah sehingga harga saham menjadi undervalued,disisi lain investor akan optimis dengan informasi yang dianggap good news.

Reaksi yang berlebihan dapat juga disebabkan oleh berbagai faktor diantaranya adalah January Effect. Fenomena January Effect merupakan pebedaan tahun dari bulan Desember sebagai akhir tahun pajak ke bulan berikutnya bulan januari yang merupakan awal tahun dan sebagai awal tahun pajak. January Effect terjadi dapat dipengaruhi beberapa faktor, diantaranya adanya pengaruh portofolio window dressing, ingin mendapatkan capital gain, untuk mengurangi pajak, kebutuhan dana untuk liburan dan sebagainya. Awal mula ditemukan January effect oleh salah seorang investment banker pada salah satu saham Amerika Serikat, Sidney Watchel pada tahun 1942 (Zacks, 2012:25). Sidney Watchel menemukannya dimulai dalam Journal of Bussiness of the University of chicago dengan judul "Ceretain Observations on Seasonal Movements in Stock Price". Adapun penyebab terjadinya January Efect dikarenakan adanya tax - loss selling, window dressing, dan small stock's beta. Tax-loss selling adalah fenomena di mana saham yang mempunyai kinerja buruk dijual untuk memperbaiki laporan keuangan, yang selanjutnya akan berdampak pada keringanan tax akhir tahun. Sedangkan untuk window dressing sama halnya dengan tax-lpss selling yang dilakukan yaitu menjual saham yang merugi dengan tujuan untuk terlihat lebih baik pada akhir tahun di dalam portofolio. Pasalnya stock's beta merupakan tren 
yang terjadi di bulan Januari ketika perusahaan kecil menawarkan tingkat pengembalian yang lebih dibandingkan perusahaan besar (Sharpe et al, 1995:81).

January effect dapat di tunjukan dengan return tidak normal yang didapatkan dari investor. Bila suatu pengumuman terdapat informasi, pasar diharapkan mampu bereaksi pada informasi tersebut. Abnormal return merupakan alat ukur untuk melihat reaksi ini. Dengan kata lain jika january effect terjadi maka investor mendapatkan abnormal return.

Pada bulan Januari menunjukkan adanya kenaikan dari harga saham 5 perusahaan yang tercantum ke dalam Indeks kompas100, kenaikan harga saham ini memungkinkan adanya January Effect saat periode pengamatan pasar modal dalam keadaan Pra dan Pasca pandemi Covid-19. Berdasarkan fenomena tersebut maka penelitian dilakukan pada indeks kompas 100 dengan alasan bahwa indeks ini terdiri 100 perusahaan yang memiliki kapitalisasi pasar dan likuiditas yang baik maka suatu pengaruh fenomena dapat diukur dengan cepat dan relatif lebih akurat.

Pasar modal dikatakan efisien jika pasar bereaksi dengan cepat dan akurat untuk mencapai harga keseimbangan baru, yang mencerminkan informasi yang tersedia (Jogiyanto, 2010). Kondisi yang berbeda sering terjadi dalam praktiknya di pasar modal, ini didasari oleh perilaku investor sebagai individu dalam menyikapi suatu informasi memiliki tindakan yang berbeda-beda baik dari segi frejuensi, waktu, dan kuantitas pembelian saham.

Penelitian terkait mengenai adanya January Effect beberapa kali sempat dilakukan di antaranya hasil penelitian dari Mellina Audina dan Kazia (2017) menunjukkan tidak ditemukan adanya January Effect pada sektor Property, Real Estate, dan Building Countruction di Bursa Efek Indonesia. Penelitian selanjutnya hasil dari penelitian Ni Made W Pradnyaparamita dan Henny Rahyuda (2017) menunjukkan bahwa ditemukan adanya January Effect pada perusahaan LQ45 di Bursa Efek Indonesia. Selain itu hasil penelitian yang dilakukan oleh Teresia Dhian Kusumawati (2017) menunjukkan bahwa ditemukan adanya 7 perusahaan yang mengalami Januariy Effect dan 11 perusahaan tidak mengalami January Effect pada perusahaan SubSektor Food and Beverage di Bursa Efek Indonesia. Hasil penelitian dari Firrisa Tsamara Munica dan Irin Yunita (2020) menunjukkan bahwa tidak terjadi January Effect pada Indeks Harga Saham Gabungan di Bursa Efek Indonesia periode 2015-2019. Hasil selanjutnya dari penelitian Ika Yustina Rahmawati dan Tiara Pandansari (2020) menunjukkan bahwa terjadinya January Effect pada perusahaan yang terdaftar di Jakarta Islamic Indexs.

Penelitian yang sudah dilakukan Osmelia,Olga tahun 2016, terdapat Overreaction dipasar Modal Indonesia tetapi tidak terdapat Januari effek. Maharani dan Witiastuti (2015) mengatakan bahwa terjadi market overreaction di Bursa Efek Indonesia baik dalam periode triwulan, semester dan tahunan akan tetapi tidak terjadi secara konstan melainkan terjadi secara separatis. Hasil penelitian pratama,purbawangsa,dan Hartini (2021) menunjukkan bahwa tidak terdapat overreaction yang signifikan pada perusahaan manufaktur.Berdasarkan latar belakang Berdasarkan atas latar belakang diatas maka rumusan masalah dalam penelitian ini : Apakah terdapat January Effect pada Indek Kompas 100 di Pasar Modal Indonesia periode 2020

\section{B. LANDASAN TEORI}

\section{January Effect}

January Effect (Efek Januari) adalah suatu kepercayaan dimana harga saham cenderung naik di bulan Januari. Efek kalender ini menciptakan kesempatan bagi investor saham untuk membeli saham di harga lebih rendah sebelum Januari dan menjualnya setelah harga sahamnya naik. Sri dan Sisdyani (2014) mengatakan January effect adalah keadaan pada bulan Januari dimana harga saham mengalami kenaikan dibandingkan bulan-bulan lainnya. Adanya peristiwa January Effect ini dapat 
dimanfaatkan sebagai salah satu bentuk dari anomali musiman yang memberikan kesempatan kepada investor untuk memperoleh abnormal return.

Anomali musiman ini hadir tergantung daripada waktu. Anomali musiman menunjukkan bahwa danya kenaikan atau penurunan harga saham berdasarkan efek musiman. Ada beberapa jenis anomali musiman antara lain:

\section{a.January Effect}

January effect adalah memungkinkan di mana akan terjadi kenaikan harga saham bulan Januari di minggu pertama.(Fitriani dan Hartini.2014)

\section{b.Week-end Effect}

Week-end Effect yaitu harga saham cenderung naik di hari Jum'at serta turun di hari Senin atau lebih dikenal menggunakan sebutan Monday effect dan Friday effect.

\section{c.Time of Day Effect}

Time of Day effect yaitu harga sekuritas saat transaksi cenderung naik pada 45 menit pertama dan pada 15 menit terakhir transaksi.

\section{d.End of Month Effect}

End of Month adalah harga sekuritas cenderung naik pada akhir hari tiap bulan.

\section{e.Seasonal Effect}

Seasonal adalah saham perusahaan yang penjualannya cenderung meningkat pada saat musim ramai.

\section{f.Holiday Effect}

Holidays effect yaitu adanya retrun positif di hari terakhir sebelum liburan berlangsung.

January effect adalah suatu fenomena anomali pasar yang berlawanan dengan konsep pasar efisien di mana keadaan harga saham mengalami kenaikan pada awal bulan Januari. Adanya fenomena kenaikan harga saham yang disebabkan oleh aktivitas mayoritas investor yang membeli saham pada bulan Januari. Pada bulan Januari Kenaikan harga saham dipengaruhi oleh beberapa faktor yaitu penjualan saham dengan harga murah yang memiliki tujuan untuk menghindari adanya pajak pada akhir tahun dan setelah itu mereka kembali membeli saham tersebut dibulan Januari dan faktor adanya kepercayaan bahwa pada tahun baru akan lebih baik dari tahun lalu dan juga investor individu lebih banyak yang bekerja mendapatkan bonus akhir tahun dari perusahaan, kemudian bonus tersebut dibelikan saham pada bulan Januari.

Munculnya fenomena January Effect dikarenakan adanya suatu hipotesis Taxloss Selling, Window Dressing, dan Small Stock's Beta (Sharpe. 1995)

\section{a.Tax loss selling}

Tax loss selling yakni para investor menjual saham yang memiliki nilai turun. Investor menjual saham dengan memanfaatkan return saham yang merugi untuk keperluan pribadi serta untuk mengurang pajak, investor menjual saham tidak berdasarkan informasi yang ada di pasar.

\section{b.Window dressing}


window dressing sama halnya dengan tax-loss selling hal yang dilakukan adalah dengan menjual saham yang memiliki kerugian besar dengan tujuan untuk merevisi portofolio akhir tahun agar terlihat lebih baik. Anjloknya harga saham pada akhir yang disebabkan oleh window dressing, anjloknya harga saham menarik para investor untuk membeli maka harga saham di awal tahun akan mengalami kenaikan.

\section{c.Small stock’ Beta}

Saham yang memiliki kapitalisasi pasar kecil dengan risiko yang lebih besar pada bulan Januari dibandingkan dengan bulan lainnya. Apabila hal itu benar maka saham yang berkapitalisasi kecil akan mempunyai rata-rata return yang lebih tinggi pada saat bulan Januari dari pada bulan laninnya.

\section{Faktor - Faktor yang Mempengaruhi Abnormal Return}

1. Return Realisasi (Actual Return)

Return realisasi (actual return) menurut Jogiyanto (2017: 283) adalah hasil dari investasi yang telah terjadi. Return ini dihitung menggunakan data historis dan menganggapnya sebagai salah satu indikator terpenting pada kinerja perusahaan. Return realisasi mempunyai fungsi untuk menentukan return ekspektasi. Return realisasi (actual return) adalah return yang terjadi pada waktu ke-t, yaitu selisih antara harga sekarang dengan harga sebelumnya $\left(\mathrm{t}_{-1}\right)$.

2. Return Ekspektasi (Expected return)

Return ekspektasi (Expected return) merupakan return yang diharapkan akan diterima investor dimasa depan. Berlawanan dengan actual return yang sifatnya telah terjadi, sedangkan return ekspektasi sifatnya belum terjadi.

\section{Pasar Efisien}

Hipotesis pasar modal yang menjadi acuan investor dalam mengambil keputusan adalah Efficient Market Hypothesis (EMH). Menjelaskan bahwa harga suatu saham akan tercermin secara penuh dari informasi yang tersedia di pasar. Konsep pasar yang efisien menyiratkan adanya suatu proses penyesuaian harga sekuritas menuju harga keseimbangan yang baru, sebagai respons atas informasi baru yang masuk ke pasar (Tandelilin, 2010:219

\section{Bentuk-Bentuk Hipotesis Pasar Efisien}

Tiga bentuk umum pengelompokan Hipotesis pasar efisien (efficient market hypothesis)(Bodie,2019:307)

a. Hipotesis dengan bentuk lemah (week-form),menyatakan bahwa harga-harga saham telah mencerminkan seluruh informasi yang ada dalam data perdagangan masa lalu.

b. Hipotesis dengan bentuk setengah kuat (Semistrong-form), menyatakan bahwa seluruh informasi yang tersedia di public mengenai prospek sebuah perusahaan telah tecermin dalam harga saham.

c. Hipotesis bentuk kuat (Strong-Form), harga saham mencerminkan seluruh informasi yang relevan tentang perusahaan, bahkan termasuk informasi yang hanya tersedia untuk orang-orang dalam perusahaan.

\section{Abnormal return}

Menurut Harahap (2012) abnormal return atau return tidak normal merupakan selisih antara return yang terjadi sesungguhnya dengan return ekspetasi. Dan menurut (Jogiyanto, 2014) menjelaskan bahwa abnormal return mengacu pada kelebihan (excess) return yang terjadi sesungguhnya di luar normal return, yaitu return yang diharapkan investor (expected return). Sedangkan menurut Barus \& Cristina 
(2014) abnormal return merupakan hasil pengurangan nilai bersih keuntungan (actual return) yang didapatkan investor dengan nilai keuntungan (expected return) yang diharapkan investor dari investasinya.

Abnormal return mengacu pada perbedaan antara pengembalian actual return dengan expected return yang bisa terjadi sebelum informasi diterbitkan atau telah terjadi kebocoran informasi setelah informasi diterbitkan (Tandelilin, 2010). Tahap perhitungan abnormal return :

1. Menganalisis actual return setiap perusahaan selama periode pengamatan. Perhitungan Actual Return:

$$
\boldsymbol{R}_{i t}=\frac{\boldsymbol{P}_{i t}-\boldsymbol{P}_{i t-1}}{\boldsymbol{P}_{i t-1}}
$$

Dimana:

$\mathrm{R}_{\mathrm{it}} \quad=$ Actual retun saham i pada hari $\mathrm{t}$

$\mathrm{P}_{\mathrm{it}} \quad=$ Harga penutupan saham i pada hari $\mathrm{t}$

$\mathrm{P}_{\mathrm{it}-\mathrm{I}} \quad=$ Harga penutupan saham i pada hari $\mathrm{t}-1$

2. Menghitung expected return saham dengan menggunakan market adjusted model. Perhitungan Expected Return :

Dimana:

$$
\mathbf{E}\left(\mathbf{R}_{\mathrm{it}}\right)=\boldsymbol{\alpha}_{\mathrm{i}}+\boldsymbol{\beta}_{\mathrm{i}} \mathbf{R}_{\mathrm{mt}}+\boldsymbol{E}_{\mathrm{i}, \mathrm{t}}
$$

$\mathrm{E}\left(\mathrm{R}_{\mathrm{it}}\right) \quad=$ Expected return sekuritas i pada hari ke $\mathrm{t}$

$\alpha_{\mathrm{i}} \quad=$ Intercept untuk sekuritas ke $\mathrm{i}$.

$\beta_{\mathrm{i}} \quad=$ Koefisien slope yang merupakan beta dari sekuritas i

$\mathrm{R}_{\mathrm{mt}} \quad=$ Return indeks pasar pada periode estimasi ke $\mathrm{t}$

$\varepsilon_{\mathrm{i}, \mathrm{t}} \quad=$ Kesalahan residu sekuritas i pada periode estimasi ke $\mathrm{t}$

3. Menghitung Abnormal Return saham perusahaan i pada periode t.

Penghitungan abnormal return antara lain:

$$
\begin{array}{ll} 
& \multicolumn{1}{c}{\text { RTNi,t }=\text { Rit }-\mathbf{E}(\text { Rit })} \\
\text { Dimana: } & \\
\text { RTNi,t } & =\text { Return tak normal sekuritas i pada peristiwa ke } \mathrm{t} \\
\text { Rit } & =\begin{array}{l}
\text { Return realisasi yang terjadi pada sekuritas i pada periode } \\
\text { peristiwa ke } \mathrm{t}
\end{array} \\
\mathrm{E}(\mathrm{Rit}) & =
\end{array}
$$

\section{Faktor - Faktor yang Mempengaruhi Abnormal Return}

\section{Return Realisasi (Actual Return)}

Return realisasi (actual return) menurut Jogiyanto (2017: 283) adalah hasil dari investasi yang telah terjadi. Return ini dihitung menggunakan data historis dan menganggapnya sebagai salah satu indikator terpenting pada kinerja perusahaan. Return realisasi mempunyai fungsi untuk menentukan return ekspektasi. Return realisasi (actual return) adalah return yang terjadi pada waktu ke-t, yaitu selisih antara harga sekarang dengan harga sebelumnya $(\mathrm{t}-1)$.

4. Return Ekspektasi (Expected return)

Return ekspektasi (Expected return) merupakan return yang diharapkan akan diterima investor dimasa depan. Berlawanan dengan actual return yang sifatnya telah terjadi, sedangkan return ekspektasi sifatnya belum terjadi 


\section{Hipotesi Penelitian}

Berdasarkan uraian latar belakang dan landasan teori maka diperoleh hipotesis penelitian sebagai berikut:

$\mathrm{H}_{1} \quad$ : Terdapat Januari Effect pada Indeks Kompas 100 di ursa Efek Indonesia periode 2020

H2 : Terdapat Overreaction pada Indeks Kompas 100 di Bursa Efek Indonesia.

H3 : Terdapat Pengaruh Januari effek Terhadap Overreaction pada Indeks Kompas 100 di Bursa Efek Indonesia periode 2020

\section{METODOLOGI PENELITIAN}

\section{Jenis Data}

Data sekunder merupakan jenis data yang digunakan dalam penelitian ini, data sekunder merupakan data primer yang telah diolah lebih lanjut dan telah disajikan oleh pihak lain. Maka data yang digunakan yaitu berupa harga saham pada perusahaan yang termasuk dalam Indeks Kompas 100 pada tahun 2020.

\section{Populasi dan Sampel}

\section{Populasi}

Populasi merupakan sekumpulan data yang mempunyai karakteristik yang sama serta menjadi objek penelitian. Populasi pada penelitian ini yaitu seluruh saham yang terdaftar pada perusahaan Indeks Kompas 100 di Bursa Efek Indonesia (BEI).

\section{Sampel}

Sampel merupakan sebagian dari populasi yang diambil karena dianggap representatif (dapat mewakili) serta memiliki karakteristik yang sesuai dengan penelitian yang akan dilakukan. Teknik untuk pengambilan sampel data penelitian ini adalah metode Purposive Sampling yang artinya teknik pengambilan sampel dengan pertimbangan tertentu (Sugiono, 2013). Purposive Samping dipilih karena tidak semua sampel memiliki kriteria sesuai dengan penelitian. Adapun kriteria pemilihan sampel yang akan digunakan di dalam penelitian adalah perusahaan yang konsisten masuk dalam Indeks Kompas 100.

\section{Metode Analisa Data}

Analisis Deskriptif

Analisis deskriptif adalah metode penelitian yang bertujuan untuk menganalisis data yang tersedia dan diolah sehingga mendapatkan gambaran umum serta memberikan jawaban mengenai fakta dan hubungan antara fenomena yang di teliti. Statistik deskriptif digunakan untuk memberikan gambaran atau penelitian tentang karakteristik variabel.

\section{Uji Normalitas Data}

Uji normalitas data merupakan salah satu syarat untuk melakukan analisis statistik parametrik. Pengujian ini bertujuan untuk mengetahui apakah sampel yang digunakan berasal dari data yang distribusi normal atau tidak. Konsep dasar dari uji normalitas Kolmogrov-Smirnov 
adalah dengan membandingkan distribusi data yang akan diuji normalitasnya dengan distribusi normal baku. Jika data penelitian telah diuji normalitas dan hasil pengujian menunjukkan bahwa data tersebut tidak terdistribusi normal, maka pengujian hipotesis menggunakan metode nonparametrik. Adapun kriteria pengujian normalitas data sebagai berikut:

a. Apabila nilai signifikan (sig) $>0,05$ maka dapat disimpulkan bahwa data penelitian terdistribusi normal.

b. Apabila nilai signifikan (sig) $<0,05$ maka dapat disimpulkan bahwa data penelitian terdistribusi tidak normal.

\section{Uji Hipotesis}

Uji hipotesis dalam penelitian ini dibagi menjadi dua:

1) Uji Hipotesis Parametrik

Uji yang dimaksud yakni uji beda tidak berpasangan atau uji Independent Sampel Ttest. Independent Sampel T-test atau uji $\mathrm{T}$ untuk dua sampel tidak berpasangan yang digunakan jika variabel yang diuji berskala rasio, namun kedua sampel merupakan sampel yang memiliki varians sama dan digunakan jika distribusi dana bersifat normal (Bambang Prasetyo, 2016).

Dasar pengambilan keputusan untuk menerima atau menolak $H_{o}$ pada uji Independent Sampel t-test adalah sebagai berikut:

a) Jika probabilitas (Asymp.Sig) $<0,05$ maka $\mathrm{H}_{0}$ ditolak dan $\mathrm{H}_{\mathrm{a}}$ diterima.

b) Jika probabilitas (Asymp.Sig) $>0,05$ maka $\mathrm{H}_{0}$ diterima dan $\mathrm{H}_{\mathrm{a}}$ ditolak.

\section{2) Uji Hipotesis Non-Parametrik}

Uji hipotesis yang dimaksud adalah Uji Mann Whitney U Test uji ini di mana akan digunakan untuk mengukur signifikasi data dua kelompok bebas berskala ordinal atau interval akan tetapi terdistribusi tidak normal. Apabila data tidak terdistribusi normal maka menggunakan uji Mann Whitney U Test dan ini terlihat setelah menggunakan uji KolmogrovSmirnov yang dilakukan untuk uji normalitas data. Adapun kriteria pengambilan keputusan adalah:

a) Jika probabilitas (Asymp.Sig) $<0,05$ maka $\mathrm{H} 0$ ditolak dan Ha diterima.

b) Jika probabilitas (Asymp.Sig) $>0,05$ maka H0 diterima dan Ha ditolak

\section{HASIL PENELITIAN DAN PEMBAHASAN}

\section{Populasi dan Sampel Penelitian}

Populasi yang digunakan dalam penelitian ini adalah perusahaan yang terdaftar dalam Indeks Kompas 100 periode 2020.

Pengambilan sampel data pada penelitian ini dilakukan dengan metode purposive sampling yang artinya metode pengambilan sampel dengan kriteria tertentu. Adapun kriteria pengambilan sampel dalam penelitian ini adalah perusahaan yang konsisten terdaftar dalam Indeks Kompas 100 yaitu 83 perusahaan atau sampel data sebanyak 996 sampel.

\section{Analisis Deskriptif}

Statistik deskriptif bisa dilihat dari nilai rata-rata (mean), maksimal dan minimum. Hasil dari statistik deskriptif penilaian selengkapnya dapat dilihat pada tabel berikut ini: 
Tabel 1

Statistik Deskriptif Abnormal Return
Descriptive Statistics
\begin{tabular}{|l|r|r|r|r|r|}
\hline Abnormal & \multicolumn{1}{|c|}{ N } & Minimum & Maximum & \multicolumn{1}{c|}{ Mean } & Std. Deviation \\
\hline Januari & 83 &,- 1771 &, 4752 &, 049797 &, 1027287 \\
Februari - Desember & 913 & $-2,1267$ &, 9305 &,- 043589 &, 2195181 \\
Total & 996 & & & & \\
\hline
\end{tabular}

Sumber: Data diolah 2021

Hasil statistik pada variabel abnormal return bulan Januari menunjukkan nila terkecil adalah $-0,1771$ dan terbesar 0,4752 . Hal ini berarti rata-rata abnormal return paling kecil terjadi pada perusahaan Selamat Sempurna Tbk yaitu -0,1771, serta yang terbesar terjadi pada perusahaan Semen Baturaja (Persero) Tbk sebesar 0,4752. Dan hasil statistik untuk bulan Februari

\section{Tests of Normality}

\begin{tabular}{|ll|r|r|r|}
\hline \multirow{2}{*}{} & \multirow{2}{*}{ Bulan } & \multicolumn{3}{|c|}{ Kolmogorov-Smirnov $^{\mathrm{a}}$} \\
\cline { 2 - 5 } & Statistic & \multicolumn{1}{c|}{ df } & \multicolumn{1}{c|}{ Sig. } \\
\hline Abnormal & Januari &, 127 & 83 &, 002 \\
& & & &, 000 \\
& Februari-Desember &, 171 & 913 &, 000 \\
\hline
\end{tabular}

a. Lilliefors Significance Correction

sampai Desember menunjukkan nilai terkecil adalah -2,1267 dan terbesar adalah 0,9305. Hal ini berarti rata-rata abnormal return paling kecil yang diterima perusahaan adalah $-2,1267$, terjadi pada perusahaan Semen Baturaja (Persero) Tbk di bulan November dan paling besar yang diterima perusahaan adalah 0,9305, terjadi pada perusahaan Waskita Karya Tbk di bulan Maret..

\section{Uji Normalitas}

Uji normalitas data terlebih dahulu dilakukan untuk mengetahui apakah data terdistribusi normal atau tidak normal. Pengujian normalitas data ini menggunakan uji Kolmogrov-Smirnov. Membandingkan dengan nilai signifikan yang mencapai taraf signifikansi yang telah ditentukan yaitu $<0,05$. Berikut ini adalah hasil uji normalitas:

\section{Tabel 2}

\section{Uji Kolmogrov Smirnov Abnormal Return}

\section{Sumber: Diolah Peneliti (2021)}

Berdasarkan uji Kolmogrof Smirnof pada tabel 4.2 di atas menunjukkan bahwa nilai Df Januari 83 dan nilai Df Februari-Desember 913 yang di mana merupakan jumlah abnormal return selama periode pengamatan. Nilai Asymp.Sig (2 tailed) dari abnormal return Januari 
memiliki nilai Sig. 0,002 dari nilai Asymp.Sig (2 tailed) dari abnormal return FebruariDesember memiliki Sig. 0,000. Dari hasil penelitian uji normalitas ini bermakna bahwa abnormal return berdistribusi tidak normal karena signifikansinya $<0,05$. Untuk uji beda akan digunakan uji nin parametric dan akan dilakukan dengan uji Mann-Whitney U Test.

\section{Uji Beda}

untuk melihat ada atau tidaknya Januari effect terhadap abnormal return pada perusahaan yang terdaftar di Indeks Kompas 100 dengan melakukan perbandingan antara abnormal return bulan Januari dengan bulan-bulan lainnya apakah cukup signifikan atau tidak ada perbedaan selama periode penelitian tersebut.

\begin{tabular}{|c|c|c|c|c|}
\hline \multicolumn{5}{|c|}{$\begin{array}{c}\text { Tabel } 2 \\
\text { Hasil Uji Mann Whitney U Test Abnormal Return } \\
\text { Ranks }\end{array}$} \\
\hline & Bulan & $\mathrm{N}$ & Mean Rank & Sum of Ranks \\
\hline Abnormal & $\begin{array}{l}\text { Januari } \\
\text { Februari - Desember } \\
\text { Total }\end{array}$ & $\begin{array}{r}83 \\
913 \\
996\end{array}$ & $\begin{array}{l}679,78 \\
482,02\end{array}$ & $\begin{array}{r}56421,50 \\
440084,50\end{array}$ \\
\hline
\end{tabular}

Sumber Data: Data diolah 2021

Test Statistics ${ }^{\mathbf{a}}$

\begin{tabular}{|l|r|}
\hline & ABNORMAL \\
\hline Mann-Whitney U & 22843,500 \\
\hline Wilcoxon W & 440084,500 \\
\hline Z & $-5,996$ \\
\hline Asymp. Sig. (2-tailed) &, 000 \\
\hline
\end{tabular}

Nilai mean abnormal return bulan Januari lebih besar dibandingkan dengan mean abnormal return bulan Februari-Desember yaitu 679,78 > 482,02. Dari nilai uji Mann-Whitney U Test, dapat dilihat bahwa output "Test Statistics" yang di mana nilai statistik Asymp.Sig. (2 tailed) adalah 0,000 sebagaimana dasar pengambilan keputusan dalam uji ini yang adalah 0.000 $<0.05$ maka dengan demikian terdapat perbedaan abnormal return bulan Januari dengan abnormal return bulan Februari sampai Desember sehingga hasil analisis ini menunjukkan terjadinya January Effect.

\section{PEMBAHASAN}

\section{Perbandingan Hasil Penelitian dengan Teori}

Abnormal return merupakan selisih antara tingkat keuntungan sebenarnya (actual return) dengan tingkat keuntungan yang diharapkan (expected return). Abnormal return dikatakan positif pada saat tingkat keuntungan yang sebenarnya lebih besar dari tingkat keuntungan yang diharapkan ataupun sebaliknya abnormal return dikatakan negatif pada saat tingkat keuntungan yang sebenarnya terjadi 
lebih kecil dibandingkan dengan tingkat keuntungan yang diharapkan. Maka fenomena January Effect dapat dilihat dari adanya abnormal return yang positif.

Hasil penelitian menunjukkan bahwa terjadinya January Effect yang di mana variabel abnormal return menunjukkan hasil yang signifikan pada perusahaan yang terdaftar di Indeks Kompas 100 selama periode 2020, hal ini berarti sesuai dengan teori yang menyatakan bahwa fenomena January Effect di tunjukan dengan adanya abnormal return yang positif. Terdapatnya fenomena January Effect atau adanya perbedaan abnormal return pada bulan Januari dapat disebabkan beberapa faktor antara lain adanya penjualan saham di akhir tahun untuk menekan pajak (tax-loss selling), selain itu para investor juga menjual sekuritas yang mengalami kerugian sebelum akhir tahun dan membeli kembali pada awal tahun, hal tersebut menyebabkan penurunan harga pada akhir tahun dan kenaikan harga pada awal tahun. Selain hal tersebut, window dressing juga dapat menjadi faktor terjadinya January Effect yang di mana window dressing mempunyai tujuan yang hampir serupa dengan tax-loss selling yaitu agar kinerja portofolio saham yang dilaporkan pada akhir tahun akan tampak baik dengan cara menjual saham yang memiliki kapitalisasi buruk pada akhir tahun dan membeli saham yang berkapitalisasi baik pada awal tahun.

Indeks Kompas 100 merupakan kelompok perusahaan yang memiliki kapitalisasi pasar dan tingkat likuiditas yang tertinggi, serta aktif diperdagangkan sehingga menjadikan indeks yang peka terhadap informasi yang masuk ke dalam pasar. Pada penelitian ini bahwa kelompok saham Indeks Kompas 100 untuk periode 2020 disebutkan terdapat abnormal return atau terdapat January Effect yang artinya kelompok saham Indeks Kompas 100 periode 2020 dapat dikatakan sebagai pasar efisien dalam bentuk lemah.

\section{Perbandingan Hasil Penelitian dengan Penelitian Terdahulu}

Hasil penelitian ini menunjukkan bahwa terdapat fenomena January Effect pada abnormal return saham perusahaan yang terdaftar di Indeks Kompas 100 periode 2020. Hasil ini sesuai atau signifikan dengan hasil penelitian yang dilakukan oleh Ni Made W Paradnyaparamita dan Henny Rahyuda (2017) dan Theresia Dhiana Kusumawati (2017) yang menemukan bahwa terdapat fenomena January Effect di Bursa Efek Indonesia. Akan tetapi hasil dari penelitian ini tidak sesuai atau tidak signifikan dengan hasil penelitian yang dilakukan oleh Mellina Audina dan Kazia Laturette (2017) dan juga Firrisa Tsamara Munica dan Irni Yunita (2020) yang menyatakan bahwa tidak terdapat fenomena January Effect di Bursa Efek Indonesia.

\section{KESIMPULAN}

Berdasarkan hasil pengolahan data yang telah dilakukan dan analisis hasil dari pengolahan data maka dapat disimpulkan bahwa hasil analisis deskriptif menunjukkan bahwa rata-rata abnormal return bulan Januari dengan nila terkecil adalah -0,1771 terjadi pada perusahaan Selamat Sempurna Tbk dan dengan nilai paling besar adalah 0,4752 terjadi pada perusahaan Semen Baturaja (Persero) Tbk. serta rata-rata abnormal return untuk bulan Februari sampai Desember dengan nilai paling kecil yang diterima perusahaan yaitu -2,1267 yang terjadi di bulan November 2020 pada perusahaan Semen Baturaja (Persero) Tbk dan yang paling besar yaitu -0,9305 terjadi di bulan Maret pada perusahaan Waskita Karya Tbk.

Berdasarkan hasil yang diperoleh dari pengolahan data menggunakan uji Mann-Whitney U Test menunjukkan bahwa terdapat perbedaan yang signifikan pada abnormal return saham bulan Januari dengan bulan-bulan lainnya (Februari, Maret, April, Mei, Juni, Juli, Agustus, September, Oktober, November, Desember) selama periode tahun 2020 sehingga hasil tersebut menunjukkan terjadinya fenomena January Effect pada perusahaan yang terdaftar dalam Indeks Kompas 100 di Bursa Efek Indonesia. Hal ini dapat dilihat dari nilai $\mathrm{Z}$ sebesar $-5,996$ dengan nilai signifikansi 0,000 yang lebih kecil dari 0,05 . 


\section{DAFTAR PUSTAKA}

Abdul, Halim. 2015. Analisis Investasi dan Aplikasinya. Jakarta: Salemba Empat.

Bondt, W. F. M. B, \& Thaler, R. (1985). Does the Stock Market Overreact? The Journal of Finance, 40(3), 793-805.

Bodi,Kane,Marcus. 2019. Dasar dasar Investasi, Jakarta:Salemba Empat

Fahmi, Irham. 2014. Analisa Kinerja Keuangan. Bandung: ALFABETA.

Jogiyanto, Hartono. 2013. Pasar Efisien secara Keputusan. Jakarta: PT. Gramedia Pustaka Utama.

Jogiyanto. 2014. Teori Portofolio dan Analisis Investasi. Edisi Kesepuluh. Yogyakarta: BPFE.

Karmila, Ida. 2018. Pasar Modal, Yogyakarta; KTSP

Tandelilin, Eduardus. 2010. Portofolio dan Investasi Teori Aplikasi. Edisi Pertama. Yoyakarta: KANISIUS

Jurnal:

Audina, M. (2017). January Effect Pada Sektor Property, Real Estate, dan Building Construction. JURNAL RISET AKUNTANSI DAN KEUANGAN, 5, 1337-1348.

Indrayani. (2019). ANALISIS FENOMENA JANUARY EFFECT. Jurnal Ekonomi dan Bisnis Volume 20, Nomor 1, 39-50.

Jogiyanto. (2014). Teori Portofolio dan Analisis Investasi. Edisi Kesepuluh. Yogyakarta: BPFE.

Kusumawati, T. D. (2017). FENOMENA JANUARY EFFECT DI BURSA EFEK INDONESIA PADA PERUSAHAAN. GEMA, $I X, 52-59$.

Munica, F. T. (2020). ANALISIS JANUARY EFFECT TERHADAP INDEKS HARGA SAHAM. JMM Online Vol. 4 No. 1 Januari (2020) , 4, 76-85.

Pradnyaparamita, N. M. (2017). PENGUJIAN ANOMALI PASAR JANUARY EFFECT. E-Jurnal Manajemen Unud, 06, 3513-3539.

Rahmawati, I. Y. (2020). Pengujian Anomali January Effect Terhadap Saham Pada Perusahaan. MEDIA EKONOMI, 20, 6-15.

Sisdyani2, F. A. (2014). ANALISIS JANUARY EFFECT DI PASAR MODAL INDONESIA. EJurnal Akuntansi Universitas Udayana 6.2 (2014):237-248, 237-248. 